This item was submitted to Loughborough's Research Repository by the author.

Items in Figshare are protected by copyright, with all rights reserved, unless otherwise indicated.

\title{
Fragments in the realization of relativism
}

PLEASE CITE THE PUBLISHED VERSION

PUBLISHER

Sage Publications Ltd @ The author

VERSION

AM (Accepted Manuscript)

LICENCE

CC BY-NC-ND 4.0

REPOSITORY RECORD

Potter, Jonathan. 2019. "Fragments in the Realization of Relativism". figshare. https://hdl.handle.net/2134/9491. 


\section{ㄴoughborough University}

This item was submitted to Loughborough's Institutional Repository (https://dspace.lboro.ac.uk/) by the author and is made available under the following Creative Commons Licence conditions.

\section{Ccreative}

$\begin{array}{llllllllllllllllllll}\text { C } & \mathrm{O} & \mathrm{M} & \mathrm{M} & \mathrm{O} & \mathrm{N} & \mathrm{S} & \mathrm{D} & \mathrm{E} & \mathrm{E} & \mathrm{D}\end{array}$

Attribution-NonCommercial-NoDerivs $\mathbf{2 . 5}$

You are free:

- to copy, distribute, display, and perform the work

Under the following conditions:

Attribution. You must attribute the work in the manner specified by the author or licensor.

Noncommercial. You may not use this work for commercial purposes.

No Derivative Works. You may not alter, transform, or build upon this work.

- For any reuse or distribution, you must make clear to others the license terms of this work.

- Any of these conditions can be waived if you get permission from the copyright holder.

Your fair use and other rights are in no way affected by the above.

This is a human-readable summary of the Legal Code (the full license).

$$
\text { Disclaimer 만 }
$$

For the full text of this licence, please go to: http://creativecommons.org/licenses/by-nc-nd/2.5/ 


\title{
Fragments in the Realization of Relativism
}

\author{
Jonathan Potter
}

Discourse and Rhetoric Group

Department of Social Sciences

Loughborough University

Loughborough

Leicestershire, LE11 3TU

Email: J.A.Potter@lboro.ac.uk

Tel: 01509223384

Fax: 01509223944

For: I.Parker (Ed.) Social Constructionism, Discourse and Realism. London; Sage.

17 March, 2012 
Why use a textual form of fragments here? I want to resist the implication that I am putting together an orderly philosophical argument. It seems appropriate that a relativist textual form will be disorderly, promiscuously moving between different kinds of discourse, and speaking in a range of different voices and experimenting with alternative subject positions. The aim is not use the discourses of philosophy; instead it will be a set of comments and interventions based around rhetoric. So, in (almost) no particular order, some fragments...

The 'relativism-realism debate' is a literary construction

The realism/relativism debate is a literary construction. That is, it is produced in narratives which invoke a range of tropes and produce a set of characters: realists, materialists, constructionists, relativists. The trouble is that when a debate gets going it is 
hard to sustain disbelief in the solidity of these characters. On any particular occasion of argument the characters appear solid, coherent and timeless and the argument slips the clutches of the indexical now and turns into something abstract and universal. Philosophical discourses tug us toward the timeless and abstract; a rhetorical corrective (doing rhetoric in the process) stresses the situated and practical nature of such arguments.

So I am claiming that we should avoid the debate because it is literary construction? Yes and no. Yes, the debate should be resisted, because the very taking part starts to reify its elements (even writing like this does it: writing of „the debate projecting back to Protagoras (say) rather than being something worked up locally for a conference at Manchester Metropolitan University (say)). But also no, in the sense that these discursive processes are a generic and omnipresent part of debates; the specific constructions can be resisted and commented upon, but there is no ideal world of debate insulated against such processes.

Highlighting the literary nature of 'the' debate (\#1: with history)

One way of emphasising the locality and literality of debates about realism is look to history. If we take just the recent history of social psychology and some of its border zones, we can see the way that there is not one single realism/relativism debate carrying on like a piece of trench warfare with new troops arriving at the front when others get exhausted, shot down or just plain bored. Rather there are a range of debates with their own rhetorical targets and moral heroes based around issues such as rationality, positivism, and naturalism. Realism has been constructed in particular ways and directed at specific targets: for example, in the 1970s Rom Harré (e.g. Harré and Secord, 1972) took on experimental social psychologists while Roy Bhaskar (e.g. Bhaskar, 19**[JTSP paper]) defended Marxism and 
psychoanalysis against Popperian critiques, while, more recently still, John Greenwood (e.g. 1994) uses realist philosophy to rework social constructionist developments into a more conventional experimental fold. In this historical story, then, realism is constructed according to its rhetorical targets.

Highlighting the literary nature of 'the' debate (\#2: with sociology)

Sociologists of science (another literary construction) have produced analysis which can highlight the literary nature of this debate in another way. Instead of being concerned with the rhetorical nature of broad debates in philosophy of social science they have been more interested in considering the practical ways that scientist use notions of reality in the course of doing their jobs. On the one hand, they have emphasised that scientists — and this is proper, hard nosed scientists — cannot fail to move between realist, constructionist, conventionalist discourses as they do different things (Latour and Woolgar, 1986). It is wrong, therefore, to think of physicists, say, simply as realists; as wrong as it would be to think of theologians, say, simply as constructionists. On the other hand, some sociologists have suggested that different areas of science gravitate toward different philosophies, as they make the best general sense of their findings and theories. For example, Knorr Cetina (1995) suggests that while microbiologists [check] tend toward a philosophical realism, the high energy physicists working on the massive particle detector at CERN tend towards a form of relativism. 
An analogy emphasising rhetoric and context

Here is an analogy to help think about the potential importance of rhetoric and context to „the" (now established as really fictional) debate. Consider this. We are faced with a piece of paper with "too many cooks spoil the broth" written on it. What are we to do?

One course would be to immediately set up a study to see if it is right. We might have some philosophers working on logic of „too many", or we might have some experimentalists setting up studies of cooking with three, four or even five cooks who are all producing broth

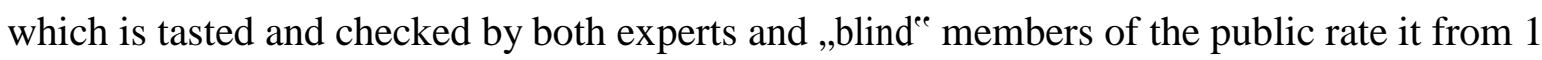
(totally spoiled) to 7 (not at all spoiled). The aim of this line of research would be to assess whether "too many cooks spoil the broth" is true or not. If it checks out this will be a green light for people to go on saying it with confidence, if not it will be a licence for these researcher to intervene whenever this claim is wrongly made and point out the error.

The other course would be to treat what is written on the paper as a piece of transcript; that is, as a record of something said on a particular occasion as a part of a particular activity. This would pay attention to the context dependent (,indexical ${ }^{\text {ee }}$ ) nature of the utterance (note: utterance, not just a sentence now) and what it is doing rhetorically. For example, is it part of an argument against, or justification of, limiting the people involved in some task. This is the approach to proverbs taken by Harvey Sacks (1992) and Michael Billig (1987) — and it is very much not the approach taken by numerous writers of introductory social psychology textbooks. If we follow through the example with the case of realism, the implication would be to say that there is not a general problem of realism; instead there are a whole variety of different language games in which the word real is used to do particular tasks. 
So what is realism?

Here are four kinds of realism (with examples) which appear in debates in, around, and against relativism (and constructionism) in the mid 1990s.

1. Realism as a philosophical cum social theory about the ontology of social science, how it should be conceived and, perhaps, how it should be investigated. Andrew Collier (this volume) provides some arguments in this discourse.

2. Realism as another way of describing empirical work in social psychology. For example, Beryl Curt (this volume) get close to this.

3. Realism as an alternative formulation of the marxist notion of materialism (the social theory of base and superstructure, economic determinants on social change, class conflict and so on). Parker (this volume) sometimes implies this equivalence.

4. Realism as a rhetorical commonplace in a range of more or less everyday, non-technical discourse. Slippage to this sense is endemic in realist argument against relativism. In much of the writing on the realist side in this book, however, these four kinds of realism are somewhat blurred together. Indeed, together they can provide a flexible set of argumentative resources to do a range of different tasks. (Look, it is happening again: having developed an argument against formulating a debate with sides, it then cannot resist wading in as if you could describe the sides in a realistic way, and enter the debate. Realist discourse is so seductive, so inevitable).

Why the realism-relativism debate makes no difference (\#1: philosophy is not politics)

Carla Willig quotes Terry Eagleton on philosophy and politics. He is complaining that real political questions (should troops be withdrawn from Northern Ireland?, will a 
minimum wage help low paid workers or will it increase unemployment?) need to be addressed in terms of their politics. Their answers generally do not follow from methodicoontological arguments about the nature of tables, or from the decision to treat realism as a set of more or less helpful stories rather than being just true. For this reason (among others), I disagree with Ros Gill who attacks (and I think that is the right word) relativists for offering „no principled alternative to realism by means of which we might make political interventions' (Gill, 1995: 171). Political interventions should come from political argument and commitment — relativism is neither claiming nor excluding either of these things.

Why the realism-relativism debate makes no difference (\#2: ideological dilemmas)

If there is only really solidly established empirical finding from work in discourse analysis it is that discourse is highly fragmented. Studies of peoples ${ }^{e e}$ practical reasoning about social issues show a huge amount of variation and considerable flexibility. They have identified wide discontinuities between theory and practice in different realms and found that ideological arguments tend to have a dilematic form (Billig, 1992; Billig, et al., 1988; Wetherell and Potter, 1992). For example, Ros Gille"s (1993) study of radio controlleres accounts for the low representation of female DJs found a general pattern of support for principle's of equality combined with practical reasons for failures to appoint more women. When the controllers were describing and justifying their own recruiting practice it was notable that they constructed accounts to present the lack of women as a product of external factors rather than their own desires; for example, few women apply, or listeners do not like women"s ,shrille voices.

The important point is that this dilemma between egalitarian principle and unequal practice is not something that is a problem for the controllers, something to be resolved; 
rather it is a resource that they use to sustain current practices. The contradictions are not a problem for the stability of the institution; quite the reverse, they can help sustain its current organization.

The study that Margaret Wetherell and I did of ideology, accounts and racism in New Zealand (Wetherell and Potter, 1992) found a rather more complex pattern. Notably, it traced the pattern of use of around ten rhetorical commonplaces — brief arguments, generally treated as clinching or beyond question — such as „everyone should be treated equally“e ,you have to live in the modern world“e, „you cannot turn the clock backwards ${ }^{e e}$, „injustices should be righted ${ }^{\mathrm{ee}}$. They are unproblematic and unexceptional notions that encompass many of the ideas of modern liberal thinking. It is not a list to raise eyebrows, let alone hackles. However, note the way they pull in different directions: how should injustices be righted without turning the clock backwards? The list has the same mix of principles and practical considerations that the radio controllers use to such good effect. The upshot is that it provides a highly flexible resource for doing a range of delicate activities such as arguing against Maori land claims being handled in the courts or attacking the teaching of Maori language to Pakeha (white) pupils.

The point of this jog through some areas of recent discourse analysis is its implication for the relation between the realism relativism debate and particular political positions and actions. It suggests that it is rather hard to tell what kind of politics will go with broad principled claims about the metaphysical nature of the objects of science or the fallibility of knowledge. 
Why it makes no difference (\#3: religion, politics and the Internet)

Another way of conceiving of the relationship between abstract positions and political theories and practices is that it is something to be worked up; it is constructed and made to seem apparently obvious, straightforward and unproblematic in particular settings. It is not a fact of nature that forces itself on all comers.

A good place to look for such constructions is on the Internet. In the week of writing this I have done several searches using AltaVista ${ }^{\mathrm{TM}}$, an engine which looks for words and strings within Web pages. Searching for the term „relativisme generates what is described as „about 800 hundred matches ${ }^{\text {ee }}$. The patterning of these is fascinating. Taking the first hundred (which AltaVista ${ }^{\mathrm{TM}}$ judges the most relevant), discussion between anthropologists of „cultural relativism ${ }^{\text {ee }}$ is heavily represented, as are postings from (apparently) philosophers on relativism and ethics. Many of these are pages including reading lists designed for particular courses. There are some science studies pages, a couple of entries on social constructionism and management science, and a page on Zen and Relativism. However, what interests me here are two kinds of pages that are also well represented: pages addressed to Christianity and relativism, and pages on relativism and political correctness.

The Christian pages vary. There is one that seems to be trying to produce a postmodern account of Christianity. Most, however, are more or less extreme attacks on relativism. A not untypical page (Two Worldviews on collision course, by Dr. K. Alan Snyder) starts:

Two worldviews are in conflict in America. That conflict is becoming more evident. On one side is the Biblical worldview that amphasizes God"s absolute moral standards, man"s sinfulness, and the forgiveness that God wishes to bestow on all who truly repent of their sins. On the other side is the humanistic worldview that stresses moral relativism, man"s basic 
goodness (although how "goodness can be defined under the umbrella of moral relativism is an open question) and the total acceptance of all types of behaviour.

From this beginning it moves on to an attack on the humanistic worldview for failing to condemn homosexuality („We should discriminate — that is, discern the difference — between proper sexual conduct and a perversion of sexuality"e), for perpetuating the myth that „normal ${ }^{\text {ee }}$ people are at risk from AIDS, and for allowing homosexual adoption: „Sodom and Gomorrah offer a poignant testimony of the ruinous effects on societies engaged in rampant homosexual behaviouree. And so it goes on...

The relativism and political correctness pages also vary. As an unsophisticated outsider to US politics, I suspect that they are produced by people will allegiance to various elements of new right thinking. The general complaint is that young people in America are increasingly succumbing to the malaise of moral relativism, and this prevents them being able to make judgements about (US) cultural superiority, or concerning the superiority of particular (often white) practices over other (often black) ones. For example:

\section{Are Relativists really successful in modern society?}

Oh, yes. Anywhere you see "multiculturalism", "conflict resolution" or "political correctness" mentioned somewhere you can be sure a Relativist is around somewhere

The blending of relativism and political correctness is fascinating as it is a complaint that people are both excessively unevaluative and over-ready to exclude particular practices and descriptions; of course, this is treated as a problem of the (alleged) victims of the (alleged) malaise rather than a confusion in the diagnosis.

The construction of relativism and political correctness on the internet deserves some serious study beyond these preliminary observations. There are just two points I will pick out here. First, relativism is being treated as a threat by cultural authoritarians and supremacists and by more or less fundamentalist Christians. This may (or may not) be reassuring to those who are concerned that relativism is at odds with the kind of materialism needed for a 
systematic social critique. Second, it is notable that it is full of people constructing versions for the purposes of criticism rather than versions produced by advocates. As Barbara Herrnstein Smith (1988) notes, much of the time the version of relativism that is used in discussion, and has become taken for granted, is that produced by realists. Perhaps the most pervasive such misconception is: „anything goes ${ }^{\mathrm{ee}}$.

\section{Anything Goes}

No! Please! How many times does it have to be repeated that ,anything goes ${ }^{\text {ee }}$ is a realist slur on relativism, probably resulting from a (disingenuous?) misreading (or a failure to read?) Feyerabend ${ }^{\text {ees }}$ Against Method. Anything goes is an extraordinarily realist claim, which no relativist has any business espousing. It is a fundamental, timeless, contextless statement about the nature of causal relations, not all that dissimilar from the laws of physics or psychology. For the relativist what "goes ${ }^{\text {ee }}$ is at stake for people; it is what is constructed and argued over. Different positions, cultures and theories have different (any)things which go, or don't go, or go a bit.

Some Realists (Espoused?, Self-styled?)

Hans Eysenck

Chris Brand
Roy Bhaskar

Ian Parker 
Reflexivity is the key

Why is reflexivity the key? It is all to do with authoring. Somewhere embedded in realists critiques of relativism is generally a „knock down“example that demonstrates the unavoidable effect of „the real"e on some part of human life. For example, in Death and Furniture (on which, more below) Derek Edwards, Malcolm Ashmore and I (1995) discuss the (almost) relativist Harry Collins ${ }^{\text {ee }}$ bottom line case — the case where „the real ${ }^{\text {ee }}$ obtrudes beyond any negotiation — which happens „as we stumble against a rock (Collins, 1990: 50). Whatever else can be questioned and reconstructed (neutrinos, gravity waves, the Health Service) the rock is a brute physical event, in which „our actions are caused directly by the rock rather than by our interpretations of what the rock is ${ }^{\text {ee }}$ (Collins, 1990: 50). The point is that it is easy to miss how Collins example is not a brute bit of reality: it is authored, and the authoring produces the brutality of the reality impingement. In real (!) cases, of course, everything may be up for grabs.

Stumbling is wonderful, with its aura of happenstance and unintentionality; it is surely no accident that ,stumbling over is is both a description of an action/behaviour and a more idiomatic gloss on finding something by chance. Such things are often precisely what is at issue in practical situations, whether the concern is how come baby Duncan broke his toy or how come Sue circulated that memo. And rock is brilliant too, with its generic, uncultured quality; it is a prototypical thing; what could be more real than that? A real (that is, not [yet] produced in a literary narrative) rock might, ironically, be more open to the usual range of interpetative questions: is it actually an artefact?, a bit of tree?, hard mud?, a stage prop?, something invented to account for a nasty bruise got in a fight with the over the road?, the door to a secret tunnel? Authoring the example is a reality defining practice, and as such, 
authored examples of this kind are ideal for arguing the case for realism; they have their realism built in.

Some examples from the conference and the book of the conference:

Andrew Collier"s open door, and his version of Estersen"s version of a dysfunctional family

Ruth Meerten"s problems in disciplining her unruly children

Ian Burkett"s version of Latour"s construction of human/machine hybrids

Oh, and am I not authoring quite a lot in this chapter? Yes indeed; but I am embracing authoring, and accepting its pervasiveness, not pretending it is not happening and disattending to its consequences. Authoring is the biz.

Reflexivity, Authoring and Experimental Social Psychology

Ironically, perhaps, the closest analogy I can find to the kind of reality presupposing practice used in realist arguments against relativism is the use of vignettes in experimental social psychology. In our critical discussion of work on attribution theory one of the things that Derek Edwards and I (1992, 1993) stumbled across was that way attribution theory research is overwhelmingly done using vignettes („,John laughs at the comedian“, „Sue is afraid of the dog ${ }^{\text {ee }}$ ) which are reality presupposing. The real world issues about whether John is laughing or sneering, or whether it is at the comedian or not, or, more significantly, what someone is doing by telling us that John laughs at the comedian, are defined out of existence. The participants in such studies do not encounter reality with all its relativising doubts and uncertainties, but a vignette where much of the business is already authored. The authoring itself is never examined — reflexivity is as corrosive for experimental social psychology as it is for realist philosophy. 
Goodbye agency, hello person talk (etc.)

One of the concerns expressed by some of the sorts of social psychologists who care about constructionism is that a proper, psychological, notion of agency is lost in newish postmodern, post-structural, relativistic, discourse analytic, ethnomethodological, constructionist work (Burr, 19** [construction primer], this volume; Madill and Doherty, 199*). These concerns are well justified. This strand of work raises very deep problems with the many of the ways in which persons have been constructed in a wide range of psychological and social psychological perspectives. That idea of a solid inner furniture that the right kind of investigation could catalogue has become increasingly difficulty to reconcile with, for example, close studies of the use of personological language in specific occasions of use (Coulter, 1990; Edwards, 1994).

People are simultaneously constructing versions of the world and of their mental states and contents as they do a whole range of business. Objective, natural, bottom line type phenomena such as emotions suddenly become delicately organized constructions doing a range of subtle business, put together for the occasion but abandoned as if never existing when another job becomes relevant a few moments later (Edwards, 1997). And yet if nostalgia for something more solid and graspable and, well, plain psychological, is put aside, this approach can be seen to be getting at very deep and subtle issues about self, relationships and feelings in a way that traditional work has missed on its continued search for some solid inner stuff (Edwards, 1996; Wetherell, 199* [reply to Madill]). 
Relativism, discourse analysis and transcription

Eh?! These topics do not seem to go together at all. Yet there is an interesting relation here. It sometimes seems like a self-evident consequence of relativism that research is not important — why do it if everything is social constructed? A systematic, reflexively applied, constructionism accepts that everything has that status. Nothing is outside the net of theories, frameworks, descriptive assumptions, rhetorical commonplaces. But this is true of theorizing (big or small, grand or middle range, grounded or airy) and good old commohn sense. Emprical, analytic research can be a great way of disciplining argument. Relativism is not a reason for sloppiness or vagueness; nor is it a licence for doing research badly (although it is always aware that notions such as badly and vagueness can, at any moment, become the issue).

Take transcription, for example. It might easily be thought that a concern with good quality transcription is something that bothers realists, or at least those with a serious empiricist bent, but is far from relativist concern. However, the value of a representational practice such as transcription is what you can do with it, what stories you can sensibly warrant and what other stories you can undermine. A good transcription system — not the Jefferson Lite sometimes advocated in discourse analysis (Potter and Wetherell, 1987), but the full Jefferson Pilsner (e.g. Jefferson, 1985; Psathas and Anderson, 1990; ten Have and Psathas, 1995) — can throw up all kinds of reality construction business going on in talk, as well as highlighting some of the decontextualizing practices that have gone on in some discourse analysis using interviews (on this see Myers, 1996; Potter and Wetherell, 1995; Suchman and Jordan, 1990). 
Realism as rhetoric (\#1: some basic rules of production)

There are various kinds of rhetoric that can be used to construct the reality and sense of realism and the problematic status of relativism and/or constructionism. Here are some useful rules (developed from Potter, 1992) to sustain the plausibility of realism. Treat them as a rhetorical kitbag that can be drawn on as and where they are needed to debunk foolish relativists.

1. Construct constructionism as something simple and unitary. The weave of different approaches, levels of argument, and quality can be sidelined.

2. Avoid reflexivity at all costs. It will soon eat away at any neat claims and foreground their rhetorical status.

3. Avoid considering empirical studies of science. They will only get in the way of the orderly progressive stories needed to butress realism.

4. Treat scientific practice as governed by logic. Local practices of inference get awfully messy, keep to networks and deductive systems.

5. Elide everyday and philosophical notions of realism. The philosophical notion gives credibility the everyday notion builds up an air of self evidence.

6. Treat description as something obvious. The business need to do description starts make realism problematic.

Realism as rhetoric (\#2: Death and Furniture (a story) and (a tetchy) defence)

Death and Furniture came to be written as a response to experiences that Derek Edwards, Malcolm Ashmore and I had while giving seminars which dealt with discourse 
analytic, reflexive or constructionist material. At question time we were repeatedly faced with two kinds of criticism. The first involved the questioner hitting the table: „you are not telling me that this (bang) is a social construction; what about the bruise I get if I walk into ite. This was so regular that we called it the furniture argument. The second was more oblique in faceto-face settings, although it is common enough in print, and that is that relativism promotes, or at least allows, a moral vacuuousness which allows a softening of the reality of the massacres of fleeing Iraqis on the Basra Road, say, and is without the full resources for criticising practices such as female genital mutilation. The aim was to be able to produce a paper which deconstructed the rhetoric of those arguments so that whenever someone produced one at a seminar we could say „Ah, the furniture argument ${ }^{\text {ee }}$, say, and (metaphorically) slap the fully rebutting paper down on that same table in front of them, and perhaps be able to move the discussion on to more interesting ground.

I am not going to repeat the arguments of the paper here. However, I do want to emphasise some features relevant to the attack recent by Ros Gill (1995).

Gill complains of a „self-righteous and dismissive tone ${ }^{e e}$ (1995: 172), an „epistemological correctness ${ }^{e e}$ even, but is perhaps forgetting that Death and Furniture is a 3rd turn; it is a response (3rd) to an accusation (2nd) that a discourse analytic talk (1st) has propounded either something close to stupidity or something close to moral degeneracy. I suspect that whatever „tone ${ }^{e e}$ there might be should be appropriately heard in that context. And it is interesting, at the very least, to note how Gillees blurring of relativism with political correctness repeats the right wing Internet tropes which endlessly mix relativism, multiculturalism, feminism and political correctness as evils to be derided.

Gill attributes to Death and Furniture the view that the academy is „,a separate realm, divorced from the political and personale (1995: 174) and claims „disinterested inquiry is their regulative ideale (1995: 175). I am not quite sure how Gill gets to this view; however, my 
own version of the implication of Death and Furniture, insofar as it has one, is that the relationships between these kinds of philosophical/rhetorical arguments and specific and practical political issues are loose, or, as I noted above there to be constructed. Just as realism can give you Eysenck and Bhaskar; relativism can give you Mussolini (according to ONeill, 1995, anyway) and Judith Butler (according to Gill). Such listings are themselves flexible and occasioned. This is not an argument for disinterest but a recognition of the complexity of political argument and the way realism and relativism may play different roles in different situations (cf. Kitzinger, 1995).

In a familiar move, Gill asserts that relativism is contradictory: contradictions there are. For whilst realist have a coherent and principled basis for their arguments, grounding them in ontological discourse, relativists do no. They offer no principled basis for choosing between any number of competing versions of events or phenomena, since they have neither ontological commitments nor explicit political commitments which inform their work (1995: 174).

This seem to be the claim that realism is simply coherent by definition. Coherence is made equivalent to „grounding“ (such a wonderfully chosen word) in... „ontological discourse“ (a beautiful oxymoron which cooks its broth and drinks it simultaneously). And given that one of the topics of relativist, constructionist analysis is precisely the rhetorical business that goes into making the choice between versions seem to be a matter of principle, or rule following, or something explicit and formal (e.g. Gilbert and Mulkay, 1984; Gill, 1993; Potter, 1996; Wetherell and Potter, 1992), it would be very odd to start pretending that principles do the job on their own (without commitment, interests, happenstance, authority, habit, the unconscious even). To this kind of idealism all a relativist can, surely, say is: get real! 
Realism as rhetoric (\#3: everyday and political uses of realism)

As I have already noted, one of the beauties of realist philosophical argument is the possibility of blurring together the abstract ontological arguments with the everyday tropes of realism talk. The patterning in these tropes can start to become clear if you look at a lot of them. For example, I took a year"s worth of US broadcast news (including CNN, abc, and Public Broadcasting System programmes) which are (conveniently, but poorly) transcribed onto CD and searched it for uses of realist, realism and realistic. The numbers come out like this:

$\begin{array}{ll}\text { Realist: } & 37 \\ \text { Realism: } & 85 \\ \text { Realistic: } & 648\end{array}$

Being realistic, then, is a recurrent trope in these materials. It is used in a range of senses, typically contrastive. Being realistic can be contrasted to being idealistic; it can emphasis an awareness of human limits, both physical and psychological; it can emphasise rationality and awareness of potential failure rather than ideology and hope. The following illustrate some of these features:

HANSEN: Do you think it is realistic for Mangosuthu Buthelezi to insist that the Zulu kingdom be autonomous, that it returns to the pre-1880s?

Prof. GUY: I do not. How can we- How is it possible to turn back the clock in this fashion? How is it possible to ignore what has happened in the last hundred years? That's one problem. There are other problems, as well. (NPR, 17/04/94)

KING: Is it a foregone conclusion, Mary, that you will get full-blown AIDS? I mean, is that automatic in this story? 
Ms. FISHER: Well, it's- it's automatic because that's what happened. That's the norm. That's what usually happens. I can hope that I won't, but- you know, we are optimistic, but we have to be realistic.( CNN, 15/04/94)

Student: $\quad$ The kids have sex. And if you're gonna teach anything about it, then you
should teach them to be safe. And abstinence is the only 100 percent way to
be safe, but today that's not a- it's not realistic to only teach that kind of
solution. (CNN, 18/03/94)

WOOTEN: [voice-over] Dr. Kunrad Hinkerts of Belgium, who led the first medical team in two weeks ago, takes a realistic view of his task.

HINKERTS: It's physically impossible to help- to bring in help for one million people who arrived in three days' time. I think nobody can help at this moment. We do our best. You can bring in and you can help the people as much as you can, but I think the disaster was- you could not do anything (ABC, 01/08/94).

Note the way that being realistic is treated as a the good or right alternative in these cases; this positive semiotic is almost invariable in the examples I have looked at. Indeed, realism in this discourse seems akin to community as a notion with no negative pole. Note also the way that being realistic is contrasted to being idealistic or optimistic. It might be nice for an HIV+ woman to hope not to get AIDS, but it is not realistic; nor should a doctor with a single team treating many refugees expect to do much.

There are a great many interesting features of this material, and the precise way that notions of realism are being used. However, I wish to make just one observation. In recent criticisms of relativism, and of the relativistic elements in discourse research, the claim has been made more than once that relativism saps political practice by disallowing the commitment of true belief (Parker and Burman, 1993). Yet in this material it is not, I think, 
too far fetched to see the tropes of realism being used to eat away at ideals and ideology, reducing abstract political arguments to pragmatism and realpolitic.

Realism as rhetoric (\#4: constructing reality as a general topic of study)

Although the deconstruction of realists" explicit argumentative tropes, whether in their philosophical form or their more everyday variety, is interesting and valuable. I think it is more important to look at realism more generally in the sense hinted at (but not followed through) by Berger and Luckmann in their Social Construction of Reality. The idea that reality is socially constructed has often remained something of a slogan; the idea that everything might be socially constructed, including the texts of the researcher has even become something of an embarrassment at times.

However, recent research on fact construction in the very different traditions of ethnomethodology, sociology of science and postmodernism has opened the possibility of addressing the construction and stabilization of versions of the world rigorously and systematically. One way of thinking of this work is as an intensive analysis of the tropes and commonplaces of everyday realism and how they are deployed in particular occasions. For example, in Representing Reality (1996) I examined some of the procedures through which the potential discounting of versions as interested is managed and the way category entitlements to knowledge are built up. The book also explores a range of techniques through accounts are made to seem objective and independent of their authors. Without going into any detail, this work is attempting to take seriously the ethnomethodological injunction to move from looking at realism as a resource to taking it as a topic.

So does this work have implications of a more general political and ethical kind? Perhaps. At least it highlights two points. First, it shows up the enormous subtlety and 
sophistication of peoplees everyday practices of fact construction. And this raises important questions about the sorts of status and authority that accrue to social scientists own factual constructions. Are we so sure we know better? Second, it encourages us again (and I think more encouragement is needed despite the impetus given by Ashmore, 1989; Mulkay, 1985, Stringer, 1985; Woolgar, 1988 and others) to consider the reality producing practices of social scientists and the tropes that they (we!) use to establish versions as solid.

Realism as rhetoric (\#5: true stories)

Realism can be a good story. There is no reason for a relativist to avoid realist narratives — indeed, it is pretty hard to do without them. There may be all sorts of purposes for which a realist story is best. Donna Haraway (1989) provides one sophisticated example of working with realist narratives. She treats her massive study of primatology, and the way in which it promotes myths of human origins and reactionary stories about gender and race, as a form of science fiction. It is telling a story about primatology, but that story draws on, yet resists the temptations of, four primary narratives: sociology of scientific knowledge, marxism, the legitimating narrative of the scientists themselves, and finally histories of gender and race and their involvement with science. Why are these temptations? Because each risks taking over the account and turning it into The One True Story, a story that takes on the mantle of timeless and unimpeachable fact. The relativist use of realist stories involves living with, and even celebrating, the tensions between them rather hiding them or forgetting them.

So this adoption of realist narrative does not elide relativism with realism. In relativism the realism never quite turns timeless, solid and true; there is always an edge of scepticism and self doubt. Ros Gill (1995) approvingly quotes Judith Butleres (1992) 
suggestion that we should have permanent contestation at the heart of any radical political project; and this seems pretty close to what relativists are after.

Why the realism-relativism debate makes a difference (\#1: members concerns)

One reason the relativism-realism debate makes a difference is that it is treated as making a difference. Every Web page, every article, every meeting at Manchester Metropolitan University builds another network of connections and stories linking (arcane?) philosophy to a range of political concerns. There comes a point where it is no longer possible to say that debate makes no difference to anything if it simply has got so big that it is making a difference.

Why the realism-relativism debate makes a difference (\#2: some virtues of relativism)

Relativism is used most happily against authority, against the status quo, against established versions and taken-for-granted realities. As Edwards, Ashmore and I (1995) wrote:

Relativism offers an every available level of resistance. It is potentially liberating, dangerous, unsettling, with an appeal that is enduringly radical: nothing every has to be taken as merely, obviously, objectively, unconstructedly, true. Reality can only ever be reality-as-known, and therefore, however counter-intuitive it may seem, produced by, not prior to, inquiry. For what counts as reality is, for any particular item, at least potentially a matter of consensus and disputation (1995: 39).

Its political contribution, then, such as it is, supports freeing up from established systems, change and openness. 


\section{References}

Ashmore, M. (1989). The reflexive thesis: Wrighting sociology of scientific knowledge. Chicago: University of Chicago Press.

Berger, P. \& Luckmann, T. (1971) The Social Construction of Reality. Harmondsworth: Penguin.

Bhaskar

Billig, M. (1987). Arguing and thinking: A rhetorical approach to social psychology. Cambridge: Cambridge University Press.

Billig, M. (1992). Talking of the royal family. London: Routledge.

Billig, M., Condor, S., Edwards, D., Gane, M., Middleton, D.J. \& Radley, A.R. (1988). Ideological dilemmas: A social psychology of everyday thinking. London: Sage.

Burr (constructionism book)

Butler, J. (1992) Contingent foundation: feminism and the question of „postmodernisme. In J. Butler \& J.W. Scott (Eds) Feminists Theorize the Political. London; Routledge.

Collins, H.M. (1990). Artificial experts: Social knowledge and intelligent machines. Cambridge, MA: MIT Press.

Coulter, J. (1990). Mind in action. Oxford: Polity.

Edwards, D. \& Potter, J. (1992a). Discursive psychology. London: Sage.

Edwards, D. \& Potter, J. (1993). Language and causation: A discursive action model of description and attribution. Psychological Review, 100 (1), 23-41.

Edwards, D. (1994). Script formulations: A study of event descriptions in conversation. Journal of Language and Social Psychology, 13 (3), 211-247. 
Edwards, D. (1995). Two to tango: Script formulations, dispositions, and rhetorical symmetry in relationship troubles talk. Research on Language and Social Interaction, 28 (4), 319-50.

Edwards, D. (1997). Discourse and cognition. London and Beverly Hills, CA: Sage.

Edwards, D., Ashmore, M. \& Potter, J. (1995). Death and furniture: The rhetoric, politics, and theology of bottom line arguments against relativism. History of the Human Sciences, 8 (2), 25-49.

Feyerabend, P.K. (1975). Against method. London: New Left Books.

Gilbert, G. N. \& Mulkay, M. (1984). Opening Pandora's box: A sociological analysis of scientists’ discourse. Cambridge: Cambridge University Press.

Gill, R. (1993). Justifying injustice: Broadcasters ${ }^{e e}$ accounts on inequality in radio. In E. Burman \& I. Parker (Eds.), Discourse analytic research: Repertoires and readings of texts in action (pp. 75-93). London: Routledge.

Gill, R. (1995) Relativism, reflexivity and politics: Interrogating discourse analysis from a feminist perspective. In S. Wilkinson \& C. Kitzinger (Eds) Feminism and Discourse: Psychological Perspectives. London; Sage.

Greenwood, J.D. (1994). Realism, identity and emotion: Reclaiming social psychology. London: Sage.

Haraway, D. (1989). Primate visions: Gender, race and nature in the world of modern science. London: Routledge.

Harré, R. \& Secord, P. F. (1972). The explanation of social behaviour. Oxford: Blackwell. Jefferson, G. (1985). An exercise in the transcription and analysis of laughter. In T. Van Dijk (Ed.), Handbook of discourse analysis, Volume 3 (pp. 25-34). London: Academic Press. 
Kitzinger, C. (1995) Social constructionism: Implications for lesbian and gay psychology. In A.R. D“eAngelli and C.J. Patterson (Eds) Lesbian, Gay and Bisexual Identities over the Lifespan: Psychological Perspectives. New York; Oxford University Press.

Knorr Cetina, K. (1995) Epistemic Cultures: How scientists make sense. Chicago: Indiana University Press.

Latour, B. \& Woolgar, S. (1986). Laboratory life: The construction of scientific facts. 2nd Edition. Princeton: Princeton University Press.

Madill, A., \& Docherty, K. (In press). „So you did what you wanted then": Discourse analysis, personal agency, and psychotherapy. Journal of Community and Applied Social Psychology, **. (Special issue on qualitative social psychology).

Mulkay, M. (1985). The word and the world: Explorations in the form of sociological analysis. London: Allen \& Unwin.

Myers, G. (1996) Displaying opinions: Disagreement and topic shifts in focus groups, ms. under submission.

O'Neill, J. (1995) „I gotta use words when I talk to you : A response to Death and Furniture, History of the Human Sciences, 8, 99-106.

Parker, I. \& Burman, E. (1993). Against discursive imperialism, empiricism, and constructionism: Thirty-two problems with discourse analysis. In E. Burman \& I. Parker (Eds.) Discourse analytic research: Repertoires and readings of texts in action (pp. 155-172). London: Routledge.

Potter, J. (1992). Constructing realism: Seven moves (plus or minus a couple). Theory and Psychology, 2, 167-173.

Potter, J. (1996) Representing Reality: Discourse, Rhetoric and Social Construction. London; Sage. 
Potter, J. and Wetherell, M. (1995) Discourse analysis. In J. Smith, R. Harré and L. van Langenhove (Eds) Rethinking Methods in Psychology (pp. 80-92). London; Sage.

Psathas, G. \& Anderson, T. (1990). The „practices ${ }^{\text {ee }}$ of transcription in conversation analysis. Semiotica, 78, 75-99.

Sacks, H. (1992). Lectures on conversation. Vols. I \& II, edited by G. Jefferson. Oxford: Basil Blackwell.

Smith, B.H. (1988). Contingencies of value: Alternative perspectives for critical theory. Cambridge, MA: Harvard University Press.

Stringer, P. (1985). You decide what your title is to be and [read] write to that title. In D. Bannister (Ed.), Issues and approaches in personal construct theory. London: Academic Press.

Suchman, L. \& Jordan, B. (1990). Interactional troubles in face-to-face survey interviews. Journal of the American Statistical Association, 85, 232-241.

ten Have, P. \& Psathas, G. (Eds.) (1995). Situated order: Studies in the social organization of talk and embodied activities. Washington, D.C.: International Institute for Ethnomethodology and Conversation Analysis and University Press of America.

Wetherell 199*

Wetherell, M. \& Potter, J. (1992) Mapping the Language of Racism: Discourse and the legitimation of exploitation. London; Harvester, New York; Columbia University Press.

Woolgar, S. (Ed.) (1988a). Knowledge and reflexivity: New frontiers in the sociology of science. London and Beverly Hills, CA: Sage. 